\title{
NILAI DIAGNOSTIK Rapid Test TbAg DAN MPT64 DENGAN KULTUR SEBAGAI GOLD STANDARD
}

\author{
Muhammad Nazarudin $^{1}$, Jusak Nugraha ${ }^{2}$, Aryati $^{3}$ \\ ${ }^{1,2,3}$ Program Studi S2 Imunologi \\ Sekolah Pascasarjana Universitas Airlangga Jl. Airlangga No. 4 - 6, Surabaya, Jawa \\ Timur Telp. (031)5914042 \\ e-mail : ${ }^{1}$ muhammad.nazarudin88@ gmail.com, ${ }^{2}$ jusak.nugraha@ yahoo.com, \\ ${ }^{3}$ dr_aryati@yahoo.com
}

\begin{abstract}
Abstrak
Tuberkulosis (Tb) sampai kini masih dianggap sebagai salah satu penyakit berbahaya yang ada di muka bumi. Pada tahun 2012, diperkirakan 8,6 juta orang mengidap Tb dan 1,3 juta di antaranya meninggal dunia. Mycobacterium tuberculosis sebagai penyebab penyakit Tb, dapat dideteksi dengan pengecatan BTA untuk mewarnai bagian sitoplasma dari bakteri ini. Standar terbaik dalam pemeriksaan Tb adalah kultur bakteri, namun dinilai terlalu lama dalam memberikan hasil. Beberapa produsen mengembangkan alat yang mempermudah prosedur pemeriksaan, memberikan hasil yang cepat namun tetap berkualitas, diantaranya yang beredar di Indonesia adalah TbAg Rapid Test dan MPT64 Rapid Test. Metode penelitian ini adalah analitik observasional dengan rancangan cross sectional. Dilakukan terhadap 50 responden dengan 34 responden mengidap Tb paru. Data yang diuji nilai diagnostik, uji McNemar dan uji Kappa. Nilai sensitivitas, TbAg Rapid Test dengan sampel sputum $97.5 \%$ dan isolat $50 \%$. Nilai sensitivitas MPT64 Rapid Test dengan sampel sputum $11.76 \%$ dan isolat $95 \%$. Hasil BTA dan TbAg Rapid Test juga tidak menunjukkan perbedaan berarti sehingga dapat digunakan untuk pemeriksaan skrining dan MPT65 Rapid Test dapat gunakan untuk tes biokimia setelah kultur.
\end{abstract}

Kata Kunci : Tuberkulosis, TbAg Rapid Test, MPT64 Rapid Test

\begin{abstract}
Tuberculosis (Tb) until now still regarded as one of the dangerous diseases on earth. In 2012, an estimated 8.6 million people suffering $T b$ and 1.3 million of them died. Mycobacterium tuberculosis as the cause of Tb disease, can be detected by smear paint to color the cytoplasm of the bacteria. Tb standard of the examination is bacterial culture, but is considered too long in delivering results. Some manufacturers develop tools that simplify inspection procedures, provide fast results but still qualified, including circulating in Indonesia is TbAg Rapid Test and MPT64 Rapid Test. This research method is analytical observational with cross sectional design. Conducted on 50 respondents with 34 respondents suffering from pulmonary tuberculosis. Data were tested by diagnostic value, McNemar test and Kappa test. The sensitivity, TbAg Rapid Test with a sample of sputum isolates $97.5 \%$ and 50\%. The sensitivity MPT64 Rapid Test
\end{abstract}

141 
Jurnal Biosains Pascasarjana Vol. 17 (2015) pp

(C) (2015) Program Pascasarjana Universitas Airlangga, Indonesia

with $11.76 \%$ of sputum samples and isolates 95\%. Results BTA and TbAg Rapid Tests also showed no significant differences so that it can be used for screening and MPT65 Rapid Test can be used for biochemical tests after culture

\section{PENDAHULUAN}

Indonesia saat ini menduduki peringkat ke-4 kasus $\mathrm{Tb}$ terbanyak di dunia dengan di Indonesia, kondisi tahun 2010 ditemukan 235 jumlah kasus $\mathrm{Tb}$ per 100.000 penduduk. (Mishra, 2014). Dinas Kesehatan Provinsi Kalimantan Selatan pada tahun 2013 melaporkan, Tb paru masih menjadi masalah kesehatan yang ada di Provinsi ini, ditemukan prevalensi sebesar 210 kasus per 100.000 penduduk atau $106,67 \%$ dari target 225 per 100.000 penduduk pada tahun 2011. Berdasar angka prevalensi $\mathrm{Tb}$ ini, setiap tahun diperkirakan terdapat lebih dari 7.600 penderita $\mathrm{Tb}$ dan kematian lebih dari 1.000 orang

Deteksi dengan pengecatan BTA dipilih tentu karena hal ekonomis, namun keterbatasan BTA yang sangat dipengaruhi oleh banyak faktor luar seperti kualitas pengecatan dan keahlian pemeriksa mengakibatkan ketepatan pemeriksaan ini dipertanyakan. Adapun standar terbaik dalam pemeriksaan $\mathrm{Tb}$ adalah kultur bakteri, namun tahapan inipun memiliki kelemahan karena dinilai terlalu lama dalam memberikan hasil. Walaupun pendekatan lain dalam diagnosa penyakit ini juga telah dilakukan seperti amplifikasi asam nukleat, deteksi antibody hingga menggunakan perumusan DNA dengan PCR namun tentu hal penggunaan pendekatan ini berkaitan dengan dana yang tidak sedikit dan keahlian yang tinggi (Sari, 2011)

Membiakkan $M$. tuberculosis dinilai sebagai sebuah standar pemeriksaan untuk kasus tuberkulosis.
Sensitivitas dari kultur jauh lebih baik dibanding BTA dengan hanya 10-100 organisme / $\mathrm{mL}$ specimen. Media pertumbuhan $M$. tuberculosis sendiri mirip dengan media yang digunakan untuk kultur spesies Mycobacteria lain dan umumnya menggunakan media cair maupun media padat. Media padat yang biasanya digunakan berbahan dasar telur seperti halnya media Lowenstein Jensen (LJ) atau berbahan dasar agar seperti medium Middlebrook 7H10 (Babady, 2012)

Akibat dari beberapa kelemahan pemeriksaan BTA dan kultur, beberapa produsen mengembangkan alat untuk dapat melakukan pemeriksaan deteksi $M$. tuberculosis yang dinilai dapat mempermudah prosedur pemeriksaan, memberikan hasil yang cepat namun tetap berkualitas. Saat ini tes cepat yang berkembang di Indonesia di antaranya adalah $\mathrm{Tb}$ Ag Rapid Test dan MPT 64 Rapid Test.

Pemeriksaan baru $\mathrm{Tb}$ Ag Rapid Test merupakan merupakan uji serologi untuk mendeteksi antigen M.tuberculosis. TB Antibodi monoclonal terhadap antigen yang dikode oleh gen RD1, RD2 dan RD3 digunakan untuk mendeteksi antigen ESAT-6,CFP-10 dan MPb64. Tiga genomic RD (Regions of Difference) yaitu RD1, RD2 dan RD3 dihilangkan pada BCG dan dapat dilakukan cepat, praktis dan mudah (Imawan, 2013). Gen yang menyandi ESAT6, CFP10, dan $\mathrm{MPb} 64$ terdapat pada regio $\mathrm{RD}$ yang terdelesi ini sehingga RD1-RD3 diduga 
kuat sebagai gen virulensi yang dimiliki oleh M. tuberculosis. (Gustiani, 2014).

\section{Adapun MPT64 Rapid Test} memanfaatkan protein yang juga disandi oleh RD1, RD2 dan RD3 berupa MPb64. Protein ini merupakan protein yang diekspresikan oleh $M$. tuberculosis. MPT64 rapid test ini merupakan pemeriksaan cepat terhadap protein MPT 64 ini sehingga mempermudah dalam pendeteksian $M$. tuberculosis dengan $M$. tuberculosis Complex lain dibandingkan dengan penegakan dengan pemeriksaan biokimia setelah kultur.

Kedua jenis pemeriksaan baru ini dianggap lebih mudah dikerjakan dibanding dengan pengerjaan klasik diagnosis $\mathrm{Tb}$ yang berupa pewarnaan Basil Tahan Asam (BTA) dan kultur bakteri, sehingga diharapkan penggunaan $\mathrm{Tb}$ Ag Rapid Test dapat menyentuh pelayanan kesehatan perifer dan mempercepat diagnosis penyakit $\mathrm{Tb}$ dan kemudian lebih mudah dalam pemantauan dan pengawasan kesehatan masyarakat dalam penyakit $\mathrm{Tb}$

\section{TUBERKULOSIS}

Tuberkulosis paru adalah penyakit infeksius yang terutama menyerang parenkim paru. Disebabkan oleh bakteri Mycobacterium tuberculosis. Nama Tuberkulosis sendiri berasal dari tuberkel yang berarti tonjolan kecil dan keras yang terbentuk saat sistem kekebalan tubuh membangun tembok mengelilingi bakteri dalam paru. Tuberkulosis paru ini bersifat menahun dan secara khas ditandai oleh pembentukan granuloma dan menimbulkan nekrosis jaringan. Tuberkulosis paru dapat menular melalui udara, waktu seseorang dengan
Tuberkulosis aktif pada paru batuk, bersin atau bicara (Wahyuningsih, 2014)

\subsection{Epidemiologi}

Tuberkulosis bersifat mudah menular melalui udara dan terdata menjadi penyakit kedua penyebab kematian tertinggi setelah HIV. Pada tahun 2013, 9 juta terpapar $M$. tuberculosis dan 1,1 juta diantaranya adalah kasus komplikasi dengan HIV. 1,5 juta orang meninggal dan 360.000 diantaranya diketahui mengidap HIV. 510.000 wanita meninggal akibat $\mathrm{Tb}$ termasuk 180.000 yang positif HIV. Secara keseluruhan, kasus kematian dengan komplikasi HIV adalah 50\% pada perempuan dan $\mathrm{Tb}$ adalah pembunuh nomor 1 pada wanita diusia reproduktif. Diperkirakan 550.000 anak sakit dan 80.000 anak yang HIV negative meninggal akibat $\mathrm{Tb}$ dan angka kehidupan $\mathrm{Tb}$ menurun hingga $45 \%$ sejak tahun 1990. (WHO, 2014)

Tahun 2013, Indonesia memiliki Case Detection Rate (angka temuan kasus) sebesar $60 \%$ dan 135 kasus per 100.000 penduduk dengan tertinggi di Papua dengan 302 kasus per 100.000 penduduk dan terendah di Daerah Istimewa Jogjakarta dengan 74 kasus per 100.000 penduduk. (Pusat Data dan Informasi Kementerian Kesehatan RI, 2015)

\subsection{Struktur dan Klasifikasi M.tuberculosis \\ Mycobacterium tuberculosis} adalah bakteri yang berbentuk batang dan bakteri aerob yang tidak membentuk spora. Bakteri ini adalah bakteri intraseluler yang tumbuh dengan lambat lambat dan mempunyai sifat patogen yang dapat bertahan di dalam makrofag 
inang. M. tuberculosis adalah bakteri asam-cepat karena dinding sel terdiri dari asam mycolic hidrofobik. Ini adalah komponen spesifik dari dinding sel mikobakteri dan berperan sebanyak $50 \%$ dari berat kering. Kehadiran lapisan asam mycolik yang tebal ini mengakibatkan nutrisi yang masuk terganggu dan hal inilah yang menyebabkan pertumbuhan mycobacteria lambat namun dapat meningkatkan ketahan terhadap degradasi melalui enzim lisosom.

Asam mycolic didistribusikan sebagai lapisan tebal sebagian besar di bagian eksternal dari dinding sel, sedangkan lapisan internal mycobacteria kebanyakan terdiri dari arabinogalactan, phosphalidyl-myoinositol mannosides (PIM), dan peptidoglikan. Disamping asam mycolic, ada juga komponen lain, termasuk biomolekul monnosa, lipoarabinomannan mannose-capped (Man-LAM), lipomannan terkait (LM), dan mannoglycoproteins. Mannan dan arabinomannan hadir di permukaan dan membentuk kapsul luar bakteri ini. ManLAM, LM, dan PIM semua berbagi domain mannosylphosphatidyl-myoinositol (MPI) yang memungkinkan menjadi struktur jangkar ke dalam membran plasma (Kleinnijenhuis, 2011)

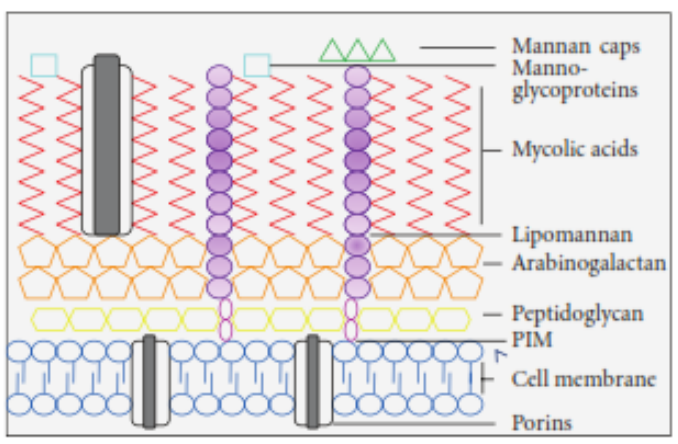

Gambar 1. Struktur dari dinding sel Mycobacterium tuberculosis.

Gambar 1 : komponen utama dari dinding sel M.tuberculosis dan distribusinya secara representatif dan skematik. Lapisan bagian dalam sel terdiri dari peptidoglikan yang berikatan dengan lapisan arabinogalactan secara kovalen. Lapisan terluar mengandung asam mycolic, glycolipids like lipomannan dan mannoglycoproteins (Kleinnijenhuis, 2011)

Sekitar tahun 1950, Timple dan Runyon membuat klasifikasi mikobakterium atipikal menjadi empat kelompok berdasarkan kecepatan tumbuh, pembentukan pigmen kuning di tempat terang atau gelap, serta sifat-sifat kolonisasi. Klasifikasi Runyon memiliki kekurangan, karena tidak menunjukkan korelasi antara karakteristik kuman dengan gambaran klinis yang terjadi. Pada tahun 1979, Wolinsky memodifikasi klasifikasi tersebut dan membagi mikobakterium atipikal ke dalam dua kelompok berdasarkan potensi patogenitas dan kecepatan tumbuh. Wolinsky memasukkan Mycobacterium tuberculosis sebagai kelompok bakteri yang bersifat human pathogen, Mammalian tubercle bacilli yang kemudian disebut Mycobacterium tuberculosis complex. (Chandra, 2011)

\subsection{Evolusi dan Delesi Gen}

Suatu pendekatan untuk memahami evolusi MTBC dan mencari gen virulensi adalah dengan mengidentifikasi region of different (RD) atau mencari single nucleotide polymorphisms (SNPs). Adapun RD pada $M$. tuberculosis adalah sebagai berikut : 
- RD1 : sebuah gen pada segmentasi 9,5 kb yang ditemukan dengan 9 Open Reading Frame (ORF) dari Rv3871-Rv3879 muncul sebagai virulensi $M$. tuberculosis dan hilang secara konsisten pada semua tipe $M$. bovis BCG. Regio ini disebut sebagai RD 1. Dua dari ORF-ORF ini mengkode $10-\mathrm{kDa}$ kultur filtrate protein (CFP-10) dan protein $6-\mathrm{kDa}$ early secreted antigenic target (ESAT-6). Menariknya, delesi fragmentasi RD-1 dari $M$. tuberculosis ini menghilangkan virulensinya, sementara introduksi dari lokus RD1 kepada M. bovis BCG atau $M$. microti menunjukkan peningkatan virulensi dan property survival. (Ganguly, 2012)

- RD2 tidak ada pada beberapa strain BCG. Diantara 13 substrain BCG, 8 diantaranya menunjukkan delesi 10 kb. 2 gen mengkode protein imunogenik MPb 64 dan protein regulator LysR. Spekulasi beberapa peneliti RD2 yang hilang pada beberapa BCG mungkin bertanggung jawab atas iunitas protektif yang menurun dipicu oleh substrain BCG tersebut (Sari, 2011)

- RD3 cocok dengan satu (phiRv1) dari 2 prophage (phiRv1 dan phiRv2) dan ada dalam genom $M$. tuberculosis

- RD4 menunjukkan delesi $12,7 \mathrm{~kb}$ pada $M$. bovis dan semua strain $M$. bovis BCG.

- RD5 tidak ada pada M. bovis, M. bovis BCG dan juga M. microti meliputi 3 (plcA, plcB, plcC) dari 4 gen yang mengkode suatu suatu fosfolipase C pada $M$. tuberculosis H37Rv. Fosfolipase $\mathrm{C}$ telah dikenal sebagai faktor virulensi yang penting pada beberapa bakteri. Aktivitas fosfolipase $\mathrm{C}$ ada pada $M$. tuberculosis, M. microti dan M. bovis namun tidak ada pada $M$. bovis BCG. RD5 juga mengandung gen yang mengkode protein yang termasuk dalam kluster ESAT 6 (seperti RD1 dan RD8)

- RD6 mengandung unsur insersi (IS1532) dan gen yang mengkode protein yang banyak berulang yaitu keluarga PPE. RD6 tidak ada pada $M$. bovis, M. bovis BCG, M. africanum, M. microti juga beberapa macam isolat $M$. tuberculosis

- RD7 mengandung Mce3 operon. Sulit untuk menyatakan tentang efek mce3 yang hilang pada $M$. bovis, M. microti dan $M$. bovis BCG. RD7 tidak ada pada beberapa anggota $M$. tuberculosis complex yang tidak virulen pada manusia.

- RD8 mengandung 1 dari 6 sekuen genom yang mengkode epoxide hydrolase (EphA-F). Secara umum enzim ini dianggap sebagai enzim detoksifikasi. EphA ini mungkin terlibat dalam detoksifikasi hasil produk peroksidasi lipid. Seperti RD1 dan RD5, RD8 mengkode protein yang termasuk dalam ESAT6

- RD9 mengkode gen precorrin methylase, oxidoreductase dan exported protein. RD9 didelesi pada M. africanum, M. bovis, M. bovis BCG dan M. microti, namun tidak pada M. tuberculosis. Dalam lokus ini M. africanum mirip dengan M. bovis, hal ini mencerminkan postulat status pertengahan strain ini antara $M$. tuberculosis dan M. bovis

- RD10 mengkode protein enoyl CoA hydratase dan aldehyde dehydrogenase. RD10 tidak ada pada 


\author{
M. microti, M. bovis dan M. bovis \\ BCG
}

- RD11 cocok dengan prophage kedua (phiRv2) yang memiliki kesamaan pengaturan dengan phiRv1.

- RD12 dan RD13 berukuran 2,5 kb dan mengandung gen yang mengkode thiosulfate sulfurtransferase, molybdoprotein converting factor, methyltransferase, cytochrome P450 (RD12), transcriptional regulator, cytochrome P450 dan dehydrogenase (RD13). Tidak ada pada $M$. bovis dan $M$. bovis BCG, namun ada dalam $M$. microti.

- RD14, RD15, dan RD 16 adalah daerah delesi pada spesifik substrain BCG, RD14 hanya pada BCG Pasteur 1173P2. RD15 menunjukkan suatu spesifik delesi dari BCG substrain Frappier dan Conaught dan RD16 merupakan spesifik delesi pada BCG Moreau. Sama dengan RD2, daerah ini dapat mempengaruhi imunogentitas dari substrain BCG.

M. tuberculosis mempertahankan RD1, RD2, RD4, RD7, RD8, RD9, RD10, RD12, RD13 dan RD14 (Rastogi dan Sola, 2007)

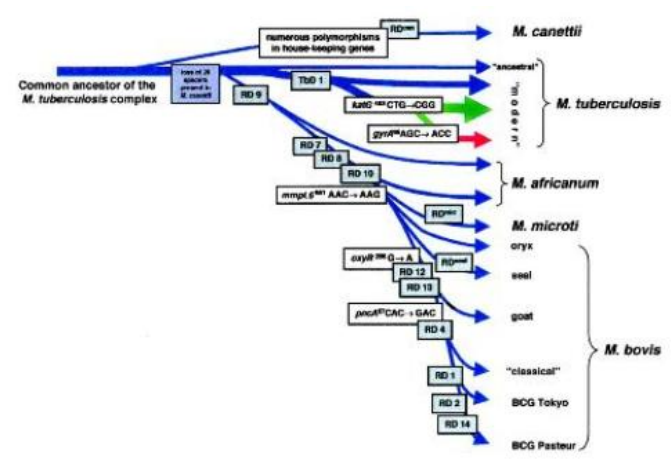

Gambar 2. Skema usulan jalur evolusi basil tuberkel berdasar pada delesi dan sekuensi polimorfisme pada 5 gen $k a t G$, gyrA, oxyR, pncA, mmp 16 dan TbD1
(Malla, 2013)

\subsection{Imunopatogenesis}

\subsubsection{Respon Imun Bawaan}

Sel fagosit berperan penting dalam mengawali dan mengarahkan inunitas menuju system adaptive yang diperani oleh sel T. Secara alami, selama memasuki paru Host, M. tuberculosis melakukan interaksi dengan reseptor yang dimiliki oleh host (PRRs), seperti halnya Toll like Receptors (TLR), complemen receptor 3, mannose receptor, scavenger receptor, DC-SIGN 3 (DC-Specific Intercellular Adhesion Molecule 3 grabbing non integrin) yang kesemua reseptor tersebut berada dipermukaan sel makrofag dan sel denrit.

Interaksi antara $M$. tuberculosis atau komponennya dengan TLR mengawali suatu kaskade alur sinyal intraselular yang puncaknya berupa suatu respon pro-inflamasi yang bermanfaat bagi host. Namun, bakteri mampu menyusun strategi yang dapat memperkecil respon imun innate dan dari sisi ini malah menguntungkan pathogen.

NADPH oxidase dan DC-SIGN yang memperantarai mekanisme fagositosis untuk menghancurkan bakteri M. tuberculosis dengan menggunakan ROS (Reactive Oxygen Species) juga akan berinteraksi dengan TLR-2 yang mengakibatkan VD berinduksi dan berlanjut dengan peningkatan produksi peptide anti mikroba. Dengan perlakuan knockdown NADPH oxidase 2 akan memodulasi ekspresi cathelicidin pada makrofag manusia sehingga menghambat aktivasi peptide anti mikroba melalui $1,25 \mathrm{D}$. 
Sitokin-sitokin seperti Interferon- $\gamma$ (IFN $\gamma$ ) dan TNF- $\alpha$ juga berperan dalam pembunuhan $M$. tuberculosis yang mana IFN $\gamma$ akan mengaktifkan makrofag dan meningkatkan pembunuhan bakteri setelah melalui prosesmaturasi fagosom. Disertai pula peningkatan produksi RNI (Reactive Nitrogen Intermediates) dan ROI (Reactive Oxygen Intermediates) oleh TNF- $\alpha$ bersama IFN $\gamma$ yang berfungsi sebagai anti-mikroba dan kemudian membentuk granuloma.

Adapun sel-sel innate yang ikut berperan dalam seperti CD1-restricted NKT cells yang bukan merupakan golongan sel T CD4+ dan CD8+ namun mampu mengenali lemak yang dipresentasikan oleh sel CD1. Sel Neutrofil dan sel $\mathrm{V}-\gamma-9 \mathrm{v}-\delta$ encoded $T$ (sel $\gamma-\delta \mathrm{T}$ ) akan cepat direkrut ke situs infeksi dan bersifat sitotoksik sebagai pertahan pertama dalam menghadapi infeksi M. tuberculosis. (Dachlan, 2013)

\subsubsection{Respon imun didapat}

Makrofag dan sel dendrit yang terinfeksi $M$. tuberculosis akan mensekresi sitokin, termasuk IL-12, IL23, IL-7 dan TNF- $\alpha$ dan akan mempresentasikan antigen kepada beberapa populasi sel $\mathrm{T}$, yakni sel $\mathrm{T}$ CD4+ (MHC kelas II) dan sel T CD8+ (MHC kelas I), CD1d-resricted $\mathrm{T}$ cell (glycolipid antigens) dan sel $\gamma-\delta$ T (phospholigands). Populasi sel $\mathrm{T}$ ini memproduksi sitokin efektor IFN- $\gamma$ dan kemudian mengaktifkan makrofag serta bersama TNF- $\alpha$ mempengaruhi pertumbuhan mycobacteria intraselular melalui ROI dan RNI. Sel T-CD8+ dapat membunuh mycobacteria intraselular dengan melepaskan granula granulysin dan perforin. Namun, CD4+Th2 Cells memproduksi sitokin bersifat imunosupresif seperti IL-4 dan sel Treg CD4+, CD25+, FoxP3+ akan memproduksi IL-10 dan TGF- $\beta$ yang berefek mekaisme efektor mycobacterisidal

Manusia bertahan dengan antigen M. tuberculosis dalam bentuk hipersensitivity tipe lambat (delayedtype hypersensitivity/DTH). Reaksi inflamasi tipe lambat tampak seperti edema setempat setelah protein $M$. tuberculosis invasi. Pada manusia dengan penyakit tuberculosis mampu mengembangkan respon berpola Th1 terhadap $M$. tuberculosis, terbukti dengan sel T-CD4+ dan T CD8+ dalam darah dan paru yang mampu merespon secara spesifik terhadap antigen $M$. tuberculosis dengan cara proliferasi dan dengan mensintesa IFN- $\gamma$ serta sitokin Th1 lainnya. (Dachlan, 2013)

\subsection{Pemeriksaan BTA}

Sputum, eksudat atau materi lain yang diuji dilakukan dengan memberikan teknik pewarnaan ZeihlNeelsen. Teknik pewarnaan ini adalah teknik yang paling sering digunakan dalam laboratorium. Pada dasarnya prinsip pewarnaan BTA adalah memanfaatkan panas dan phenol agar bias menembus lapisan lemak atau lilin yang ada di dinding sel sehingga lapisan lemak itu akan tertembus dengan zat warna dasar yaitu carbol fuchsin. Setelah terwarnai dengan carbol fuchsin dan dicuci dengan air mengalir, maka lapisan lilin yang terbuka akan kembali tertutup karena pendinginan saat dicuci. Sewaktu dituang dengan asam dan alcohol, warna merah dari fuchsin pada BTA tidak akan lepas. Bakteri yang tahan asam melepaskan warna merah sehingga akan menjadi berwarna pucat dan tidak 
berwarna. Akhirnya pada waktu dicat dengan Methylen blue, BTA tidak akan menyerap warna tersebut sedangkan bakteri yang tidak tahan asam akan mengambil warna biru dari methylene blue (Dewi, 2012)

Hapusan darah yang telah didapat kemudian diperiksa di bawah mikroskop dengan perbesaran objektif $100 \mathrm{x}$. Sehingga dilaporkan sebagai berikut :

Tabel 1. Skala IUATLD untuk pembacaan BTA (Dirjen Bina Upaya Kesehatan, 2012)

\begin{tabular}{lc} 
Jumlah BTA ditemukan & Pelaporan \\
\hline $\begin{array}{l}\text { Tidak ada BTA dalam } \\
\text { 100 lapang pandang }\end{array}$ & - \\
\hline $\begin{array}{l}\text { 1-9 BTA dalam 100 } \\
\text { lapang pandang }\end{array}$ & Jumlah \\
10-99 BTA dalam 100 \\
lapang pandang
\end{tabular}

\subsection{Pemeriksaan Kultur}

Pemeriksaan biakan metode konvensional terdiri dari media agar dan media telur (egg-based and agar-based media) seperti media LJ (LowensteinJensen) dan middlebrook agar. Kedua media tersebut merupakan media padat dan memerlukan $3-8$ minggu untuk masa inkubasi. Media cair lebih cepat menimbulkan pertumbuhan kuman. Pada dasarnya metode biakan merupakan kombinasi antara media cair dan media padat atau kombinasi bifasik (padat dan cair), guna media padat untuk memaksimalkan sensitifitas deteksi kuman. Saat ini cara tersebut merupakan standar baku emas untuk biakan kuman (Kusuma, 2007)

Dalam beberapa tahun terakhir mulai dikembangkan beberapa cara untuk mengetahui pertumbuhan kuman yang lebih cepat dan lebih dini. Beberapa diantaranya adalah

- BACTEC dikembangkan berdasarkan generasi karbon dioksida radioaktif yang berasal dari substrat asam palmitat. Cara ini telah banyak digunakan karena pertumbuhan kuman dapat dideteksi dalam 5-10 hari. Dengan menambahkan NAP $(\beta$ nitro $\alpha$ acetylamine $\beta$ hidroxy propiophenone) dapat membedakan kuman TB dari mikobakteri lain

- MGIT(Mycobacteria growth indicator tube) berdasarkan fluoresensi pada pertumbuhan kuman. Tabung gelas berisi media Middelbrook $7 \mathrm{H} 9$ yang telah dimodifikasi bersama dengan fluoresence quenching - based oxygen sensor dan ditanam di dasar tabung. Pertumbuhan kuman dengan cara ini dapat dideteksi dalam $7-12$ hari. Telah dibuat sistim baru yang sepenuhnya otomatis, yaitu BACTEC MGIT 960 system.

- MB - Redox (Heipha Diagnostica Biotest) merupakan cara manual berdasarkan reduksi terhadap garam tetra zolium di dalam media cair

- MB/Bact System (Organon) berdasarkan deteksi warna karbon dioksida, diproduksi oleh kuman yang tumbuh dalam sistim tertutup secara otomatis (automated equipment based colorimetric detection).

- ESP Culture System III (Trek Diagnostics) berdasarkan deteksi terhadap perubahan tekanan dalam media kultur yang tertutup rapat 
selama proses pertumbuhan kuman secara otomatis

- Phage - based tests atau uji mikobakteriofag sangat menjanjikan karena relatif mudah dilaksanakan, walaupun masih memerlukan infrastruktur seperti dalam biakan kuman, waktu yang diperlukan hanya sekitar 2 hari

\subsection{Pemeriksaan TbAg Rapid Test}

Pemeriksaan ini adalah pemeriksaan cepat dengan memanfaatkan protein yang disandi oleh RD1, RD2 dan RD3 M. tuberculosis. Protein ini kemudian digunakan untuk memproduksi antibodi yang kemudian dimanfaat untuk menjadi alat pemeriksaan cepat dalam deteksi antigen dalam specimen.

Pemeriksaan ini menggunakan prinsip double antibody chromatographic lateral flow immunoassay. Sampel akan mengalir ke area absorben dan membrane selulosa. Protein antigen dalam sampel akan berikatan dengan antibodi konjugat yang telah berlabel untuk membentuk kompleks antigen-antibodi dan kemudian akan ditangkap oleh antibodi yang terletak pada zona tes sehingga akan memunculkan garis berwarna merah muda. (Manual Procedure JD Biotech Tb Ag Rapid Test, 2011)

\subsection{Pemeriksaan MPT64 Rapid Test}

Protein yang disekresikan oleh $M$. tuberculosis sebanyak 33 macam protein yang berbeda-beda. Salah satu protein yang telah disekresi oleh gen RD1, RD2 dan RD3 dimanfaatkan menjadi salah satu cara deteksi dan pembeda antara $M$. tuberculosis complex dan MOTT bacilli, protein tersebut adalah MPT64.
MPT64 dideteksi dengan menggunakan imunochromatographic test yang menggunakan monoklonal antibodi tikus terhadap MPT64. Kaset tes berisi bantalan untuk sampel, bantalan untuk gold conjugate, membran nitroselulosa dan bantalan penyerap. Antibodi monoklonal tikus terhadap MPT64 diletakkan di membran nitroselulosa sebagai bahan penangkap. Antibodi lain yang bersifat sebagai epitop dari MPT64 diikatkan di partikel colloidal gold yang digunakan untuk menangkap antigen dan deteksi dalam tipe pemeriksaan sandwich.

Sampel yang diperiksa akan mengalir melalui membran dan campuran antara antibodi dan colloidal gold akan berikatan dengan MPT64 pada sampel. Kompleks ini kemudian akan berikatan dengan antibodi monoklonal tikus terhadap MPT64 pada fase solid dan akan membentuk garis berwarna merah keunguan (Manual Procedure SD Bioline MPT64 Rapid Test, 2007)

\section{METODE PENELITIAN}

Metode penelitian yang digunakan adalah analitik observasional dengan rancangan cross sectional. Penelitian ini dilakukan selama 6 bulan terhitung sejak November 2015 hingga April 2016. Pemeriksaan dilakukan di :

- BP4/Ruang Paru BLUD Rumah Sakit Umum Ulin Banjarmasin sebagai tempat pemilihan dan pengambilan sampel sputum

- Laboratorium Kesehatan Daerah Provinsi Kalimantan Selatan sebagai tempat pemeriksaan deteksi antigen tuberculosis dengan $\mathrm{Tb}$ Ag Rapid Test dan MPT64 Rapid Test pada sampel sputum, pemeriksaan kultur sputum dan pemeriksaan deteksi 
antigen tuberkulosis pada isolat kuman dengan TB Ag Rapid Test dan MPT64 Rapid Test

Populasi penelitian ini adalah penderita suspek Tb dengan hasil BTA positif dengan usia > 17 tahun baik berobat jalan maupun Rawat Inap di RSU Ulin Banjarmasin. Sampel yang digunakan sebanyak 50 sampel.

Data yang diperoleh dianalisis dengan memakai uji nilai diagnostik berupa sensitifitas, spesifisitas, nilai duga positif, nilai duga negatif, prevalensi dan akurasi. Selain uji nilai diagnostik tersebut, kemudian dilakukan uji statistik berupa Uji McNemar dan Uji Kappa untuk mengetahui kesesuaian hasil antara uji $T B$ Ag Rapid Test dan MPT 64 Rapid Test dengan kultur media Lowenstein Jensen. Uji McNemar adalah uji yang digunakan untuk mengetahui kemungkinan perbedaan bermakna antara pemeriksaan satu dengan yang lainnya, sedangkan uji Kappa dimaksudkan untuk mengetahui kekuatan kesesuaian hasil antara satu pemeriksaan dan pemeriksaan lainnya. Uji Kappa akan memberikan nilai yang menyatakan kekuatan kesepakatan hasil dengan nilai sebagai berikut (Dahlan, 2014)

\section{HASIL DAN PEMBAHASAN}

Hasil penelitian yang didapat :

Tabel 2. Gambaran Umum Hasil Penelitian

\begin{tabular}{|c|c|c|}
\hline Karakteristik & $\begin{array}{c}\text { Variasi } \\
\text { Kelompok }\end{array}$ & $(\%)$ \\
\hline \multirow{2}{*}{ Jenis Kelamin } & Laki-Laki & 64 \\
\hline & Perempuan & 36 \\
\hline \multirow[t]{3}{*}{ Usia } & $35-44$ & 26 \\
\hline & $45-54$ & 40 \\
\hline & $55-64$ & 34 \\
\hline \multirow[t]{2}{*}{ Tb Paru } & Positif & 68 \\
\hline & Negatif $\quad 16$ & 32 \\
\hline $\begin{array}{l}\text { Pada penelitian ini kelompok usia } \\
\text { responden terbanyak adalah pada usia } \\
45-54 \text { tahun dengan } 30 \% \text { dari } \\
\text { keseluruhan responden dengan jenis } \\
\text { kelamin yang lebih banyak laki-laki } \\
\text { dibandingkan dengan perempuan dan } \\
\text { juga penderita Tb Paru umumnya terjadi }\end{array}$ & \multirow{3}{*}{\multicolumn{2}{|c|}{$\begin{array}{l}\text { lebih banyak terpapar. Jenis kelamin dan } \\
\text { pekerjaan juga dinilai menjadi faktor } \\
\text { pendukung Tb paru karena sejauh ini } \\
\text { laki-laki dan bekerja sebagai buruh } \\
\text { cenderung merokok } \\
\text { Penelitian ini dilaksanakan dengan } \\
\text { melaksanakan pemeriksaan BTA, Tb Ag } \\
\text { Rapid Test dan MPT64 Rapid Test } \\
\text { dengan sampel sputum dan isolat. Jika } \\
\text { dibandingkan } 3 \text { metode ini dalam } \\
\text { menentukan screening pemeriksaan Tb } \\
\text { Paru dengan sampel sputum, Tb Ag } \\
\text { Rapid Test dinilai lebih sensitif dengan } \\
\text { nilai sensitifitas sebesar } 97.05 \% \\
\text { dibandingkan dengan hasil pemeriksaan } \\
\text { BTA dengan sensitifitas } 91.17 \% \text { dan }\end{array}$}} \\
\hline & & \\
\hline $\begin{array}{l}\text { Pengembangan Kesehatan Kementerian } \\
\text { Kesehatan dalam laporan Riskesdas } \\
\text { (Riset Kesehatan Dasar) tahun } 2013 \\
\text { melaporkan bahwa penderita Tb } \\
\text { terbanyak datang dari usia produktif. Hal } \\
\text { ini dikarenakan banyaknya kontak } \\
\text { dengan lingkungan yang memungkinkan }\end{array}$ & & \\
\hline
\end{tabular}


Jurnal Biosains Pascasarjana Vol. 17 (2015) pp

(C) (2015) Program Pascasarjana Universitas Airlangga, Indonesia

MPT64 Rapid Test dengan hanya 11.76 \%. Akurasi Tb Ag Rapid Test dan BTA memiliki nilai akurasi yang sama sebesar
$94 \%$ sedangkan MPT64 Rapid Test hanya $40 \%$.

Tabel 3. Nilai Diagnostik BTA, Tb Ag Rapid Test dan MPT64 Rapid Test dengan sampel sputum

\begin{tabular}{lccc}
\hline \multicolumn{1}{c}{ Nilai diagnostik } & BTA SPS & TbAg Rapid Test & MPT64 Rapid Test \\
\hline Sensitifitas & $91.17 \%$ & $97.05 \%$ & $11.76 \%$ \\
\hline Spesifisitas & $100.00 \%$ & $87.50 \%$ & $100.00 \%$ \\
\hline PV+ & $100.00 \%$ & $94.28 \%$ & $100.00 \%$ \\
\hline PV- & $84.21 \%$ & $93.33 \%$ & $34.78 \%$ \\
\hline Prevalensi & $68.00 \%$ & $68.00 \%$ & $68.00 \%$ \\
\hline Akurasi & $94.00 \%$ & $94.00 \%$ & $40.00 \%$
\end{tabular}

Ket : PV+ = Predicted Value Positive, PV- = Predicted Value Negative

Penting juga mengetahui kemungkinan perbedaan hasil pemeriksaan BTA, Tb Ag Rapid Test dan MPT 64 Rapid Test jika dibandingkan dengan kultur. Hasil yang diperoleh adalah BTA dinyatakan memiliki hasil yang sama dengan kultur karena nilai signifikansi yang ditunjukkan oleh uji McNemar ini adalah 0.250 atau lebih besar dari nilai kepercayaan $5 \%$ atau 0.05 sehingga dinyatakan hasil BTA dan kultur memberikan hasil yang sama. Begitu pula dengan $\mathrm{Tb}$ Ag Rapid Test yang nilai signifikansi adalah 1.000 , berbeda dengan hasil pemeriksaan MPT64 Rapid Test yang dinyatakan memberikan hasil berbeda dengan kultur dengan nilai signfikansi kurang dari $5 \%$ atau 0.05 .

Tabel 4. Hasil Uji McNemar

\begin{tabular}{lc}
\hline \multicolumn{1}{c}{ Pemeriksaan } & Significance \\
\hline BTA & 0.250 \\
\hline Tb Ag Rapid Test & 1.000 \\
\hline MPT64 Rapid Test & 0.000
\end{tabular}

Hasil Uji Kappa untuk ketiga pemeriksaan ini dengan sampel sputum, BTA dengan 0.896 dan $\mathrm{Tb}$ Ag Rapid Test dengan 0.860 yang artinya kedua pemeriksaan ini mempunyai kesepakatan yang sangat kuat dengan hasil pemeriksaan kultur. Nilai signifikansi keduanya sama yaitu 0.000 yang lebih kecil dari nilai kepercayaan sebesar $5 \%$ atau 0.05 yang berarti ada kesesuaian hasil pemeriksaan BTA dan $\mathrm{Tb}$ Ag Rapid Test dengan hasil pemeriksaan Kultur. Berbeda dengan hasil pemeriksaan MPT64 Rapid Test Rapid Test yang hanya memberikan nilai 0.079 yang berarti kekuatan kesesuaian hasil buruk dan nilai signifikansi 0.153 yang lebih dari nilai kepercayaan $5 \%$ atau 0.05 yang berarti hasil pemeriksaan MPT64 Rapid Test dengan menggunakan sampel sputum tidak memiliki kesesuaian dengan hasil pemeriksaan kultur.

Tabel 5. Nilai uji Kappa pada BTA, $T b$ Ag Rapid Test dan MPT64 Rapid Test dengan sampel sputum 
Jurnal Biosains Pascasarjana Vol. 17 (2015) pp

(C) (2015) Program Pascasarjana Universitas Airlangga, Indonesia

\begin{tabular}{lcc}
\hline Pemeriksaan & $\begin{array}{c}\text { Kappa } \\
\text { Value }\end{array}$ & $\begin{array}{c}\text { App. } \\
\text { Significance }\end{array}$ \\
\hline BTA & 0.896 & 0.000 \\
\hline $\begin{array}{l}\text { Tb } \boldsymbol{A g} \text { Rapid } \\
\text { Test }\end{array}$ & 0.860 & 0.000 \\
\hline $\begin{array}{l}\text { MPT64 Rapid } \\
\text { Test }\end{array}$ & 0.079 & 0.153 \\
\hline
\end{tabular}

Nilai sensitifitas BTA dan $\mathrm{Tb} A g$ Rapid Test lebih baik dibandingkan dengan MPT64 Rapid Test yaitu dengan $91.17 \%$ dan $97.05 \%$ dibandingkan dengan $11.76 \%$. Hasil ini tentu menunjukkan kedua pemeriksaan diatas lebih bisa digunakan untuk deteksi $\mathrm{M}$. tuberculosis dengan menggunakan sampel sputum.. Terlebih nilai uji Kappa menunjukkan keduanya memiliki kesamaan hasil yang kuat dengan gold standar. Berbeda dengan SD Bioline MPT 64 Rapid Test yang tidak memiliki kesamaan hasil dengan kultur.

Walaupun hasil pemeriksaan BTA dan $\mathrm{Tb}$ Ag Rapid Test Rapid Test memiliki nilai yang tinggi dalam semsitifitas, $\mathrm{Tb}$ Ag Rapid Test Rapid Test memiliki keunggulan tersendiri dibandingkan dengan pemeriksaan BTA karena pengerjaan yang lebih mudah dan lebih cepat sehingga juga dapat dilaksanakan di pelayanan kesehatan perifer dan sudah barang tentu akan mempermudah petugas laboratorium dalam melakukan pemeriksaan sampel sputum, walaupun harga pemeriksaan masih terbilang tinggi dibandingkan BTA.

Hal ini karena $T b$ Ag Rapid Test Rapid Test memanfaatkan protein yang disekresikan oleh $\mathrm{M}$. tuberculosis yang disandi oleh RD1, RD2 dan RD3. Sekresi protein ini terlarut dalam cairan sputum, sedangkan BTA menilai berdasar hasil pengecatan dan penglihatan petugas laboratorium yang memiliki kemungkinan eror baik dalam pengecatan maupun pembacaan. MPT64 protein yang diekspresikan oleh $M$. tuberculosis sebagai bahan yang dideteksi oleh MPT64 Rapid Test nampaknya tidak cukup banyak untuk dapat dideteksi, sehingga nilai sensitifitas MPT64 Rapid Test terbilang lemah.

Hasil penelitian ini senada dengan hasil penelitian oleh Sari (2011) Yang menyatakan hasil nilai sensitifitas $\mathrm{Tb} A g$ Rapid Test yang dilakukan di Surabaya adalah senilai $72.6 \%$ dengan $95 \% \mathrm{CI}$ : 63.3 - 79.9 dan sensitifitas $90.9 \%$ dengan 95\% CI : 72.2 - 97.5. Sri Kartika Sari menyimpulkan bahwa $\mathrm{Tb}$ Ag Rapid Test ini dapat dipertimbangkan sebagai alat diagnostik baru untuk diagnosis Tuberkulosis paru, khususnya pada tempat layanan kesehatan yang tidak memiliki teknisi laboratorium yang berpengalaman tentang pemeriksaan hasil pengecatan Basil Tahan Asam.

Menggunakan $\mathrm{Tb}$ Ag Rapid Test untuk deteksi screening pada pelayanan kesehatan perifer tentu akan lebih dapat mempermudah dan mempercepat pelayanan sehingga pelayanan terhadap pasien lebih efektif dan efisien karena berdasar pengalaman peneliti saat melakukan magang di Puskesmas pemeriksaan BTA kerap kali ditunda hingga keesokan hari karena untuk mempermudah pembacaan agar dilakukan pembacaan sekaligus dengan sampel-sampel milik pasien yang lain.

Sputum yang diperoleh dilakukan kultur dan isolat hasil pemeriksaan kultur kemudian juga dilakukan uji kepada $\mathrm{Tb}$ Ag Rapid Test dan MPT64 Rapid Test untuk mengetahui nilai 
diagnostik keduanya jika dilakukan pemeriksaan menggunakan sampel berupa isolat. Hasil yang didapat, MPT64 Rapid Test unggul dengan nilai sensitifitas $95 \%$ dan spesifisitas $100 \%$ dibandingkan dengan $\mathrm{Tb} \mathrm{Ag}$ Rapid Test Rapid Test dengan nilai sensitifitas $50 \%$ dan spesifisitas $100 \%$

Tabel 6. Nilai diagnostik $\mathrm{Tb} A g$ Rapid Test dan MPT64 Rapid Test dengan sampel isolat

\begin{tabular}{lcc}
\hline $\begin{array}{c}\text { Nilai } \\
\text { diagnostik }\end{array}$ & $\begin{array}{c}\text { TbAg } \\
\text { Rapid } \\
\text { Test }\end{array}$ & $\begin{array}{c}\text { MPT64 } \\
\text { Rapid Test }\end{array}$ \\
\hline Sensitifitas & $50.00 \%$ & $94.00 \%$ \\
\hline Spesifisitas & $100.00 \%$ & $100.00 \%$ \\
\hline PV+ & $100.00 \%$ & $100.00 \%$ \\
\hline PV- & $48.48 \%$ & $88.88 \%$ \\
\hline Prev & $68.00 \%$ & $68.00 \%$ \\
\hline Akurasi & $66.00 \%$ & $96.00 \%$ \\
\hline \multicolumn{3}{c}{ Ket : PV+ = Predicted Value Positive, } \\
PV- = Predicted Value Negative
\end{tabular}

Hasil Uji Kappa pemeriksaan ini dengan sampel biakan, MPT64 Rapid Test Rapid Test dengan 0.911 yang artinya pemeriksaan ini mempunyai kesepakatan yang sangat kuat dengan hasil pemeriksaan kultur. Berbeda dengan nilai Kappa yang diperoleh oleh $T b A g$ Rapid Test yang hanya mendapat nilai sebesar 0.390 yang artinya kesepakatan antara hasil pemeriksaannya dengan hasil pemeriksaan Kultur bernilai fair. Nilai signifikansi keduanya sama senilai 0.000 sehingga keduanya dinilai punya kesamaan dengan hasil kultur namun kekuatan hasil pemeriksaan $\mathrm{Tb}$ Ag Rapid Test lebih lemah
Tabel 5.2. Nilai uji Kappa pada $T b A g$ Rapid Test dan SD Bioline MPT64 dengan sampel isolat

\begin{tabular}{|c|c|c|}
\hline Pemeriksaan & $\begin{array}{c}\text { Kappa } \\
\text { Value }\end{array}$ & $\begin{array}{c}\text { App } \\
\text { Sionificance }\end{array}$ \\
\hline $\begin{array}{l}\text { Tb Ag Rapid } \\
\text { Test }\end{array}$ & 0.390 & 0.000 \\
\hline $\begin{array}{l}\text { SD Bioline } \\
\text { MPT64 }\end{array}$ & 0.911 & 0.000 \\
\hline
\end{tabular}

Berbeda dengan hasil yang ditunjukkan oleh pemeriksaan dengan menggunakan isolat sebagai sampel. Pada pemeriksaan ini MPT64 Rapid Test dengan mudah mendeteksi $M$. tuberculosis dibandingkan dengan $\mathrm{Tb} \mathrm{Ag}$ Rapid Test. MPT64 Rapid Test memberikan nilai sensitifitas sebesar 94 \% dibandingkan dengan $\mathrm{Tb}$ Ag Rapid Test yang hanya mendapat nilai sensitifitas sebesar $50 \%$. Walaupun keduanya dinilai sama-sama meliki kesamaan hasil dengan hasil pemeriksaan kultur, namun kekuatan kesepakatan hasil milik $\mathrm{Tb}$ Ag Rapid Test dinilai lebih rendah yaitu senilai 0.390 dibandingkan dengan 0.911 yang artinya kesepakatan hasil $\mathrm{Tb}$ Ag Rapid Test hanya dinilai sedang dan MPT64 Rapid Test bernilai sangat kuat dan nilai akurasinyapun lebih rendah dibandingkan dengan SD Bioline $\mathrm{Tb} \mathrm{Ag}$ yaitu $66 \%$ berbanding $96 \%$

Hal ini dikarenakan jumlah $M$. tuberculosis dalam satu koloni yang dilakukan pemeriksaan terhitung cukup untuk bisa dideteksi oleh MPT64 Rapid Test, berbeda dengan Tb Ag Rapid Test yang menggunakan isolat dan diencerkan sehingga protein sekresi tidak cukup untuk dapat memberikan hasil positif. Hasil penelitian Ryan Hopprich dkk (2012) menunjukkan bahwa MPT64 Rapid Test memberikan 
nilai sensitifitas $98.04 \%$, spesifisitas $98.68 \%$ PV+ $98.15 \%$ dan PV- $99.34 \%$ dibandingkan dengan hasil pemeriksaan system kultur liquid (BD MGIT960) dengan populasi sampel yang dilaksanakan di Adelaide, Australia. Kinerja dari MPT 64 Rapid Test dalam identifikasi Micobacterium Tuberculosis Complex dinilai sangat baik dengan keuntungan kemudahan prosedur kerja, waktu pemeriksaan yang tidak terlalu lama dan biaya yang relatif ringan.

Martin, et all (2011) juga melakukan evaluasi MPT64 Rapid Test yang mereka membandingkan dengan PCR sebagai gold standard dan memberikan hasil sensitivitas yang tinggi yaitu sebesar $96.5 \%$ dan spesifisitas $100 \%$. Mereka juga beranggapan tes ini mudah, sensitive dan tidak memerlukan skill dan peralatan khusus.

Berdasar hasil ini, maka MPT64 Rapid Test sangat tepat digunakan untuk pemeriksaan selektif hasil pemeriksaan kultur karena dinilai lebih cepat dan mudah dibandingkan pemeriksaan biokimia seperti PMB dan katalase.

\section{KESIMPULAN DAN SARAN}

Nilai sensitifitas $\mathrm{Tb}$ Ag Rapid Test dan MPT64 rapid test dengan sampel berupa sputum adalah $97.05 \%$ dan $11.76 \%$. Nilai sensitifitas Tb Ag Rapid Test dengan sampel isolat adalah $50 \%$ dan MPT 64 Rapid Test dengan sampel isolat adalah $94 \%$

$\mathrm{Tb}$ Ag Rapid Test dapat optimal dikerjakan dengan sampel sputum, sehingga bisa digunakan sebagai alat pemeriksaan screening pengganti BTA. Hasil pemeriksaan $\mathrm{Tb} A g$ Rapid Test tidak memiliki perbedaan yang bermakna dengan pemeriksaan BTA sehingga bisa digunakan sebagai alat untuk pemeriksaan cepat dalam skrining penyakit $\mathrm{Tb}$ paru.

Berdasar hasil penelitian ini, peneliti memberikan saran untuk melakukan penelitian dengan menggunakan kelompok negatif berupa penyakit paru non $\mathrm{Tb}$, sehingga akan diketahui jika ada penyakit lain yang dapat mengakibatkan pemeriksaan cepat ini positif

\section{UCAPAN TERIMA KASIH}

Terimakasih untuk orang tua, keluarga, istri dan anak-anak yang telah memberikan dorongan, dukungan, bantuan dan motivasi yang telah diberikan. Terimakasih juga untuk Rektor Universitas Airlangga Surabaya, Dekan dan jajaran di Program Pascasaraja S2 Imunologi yang telah memberikan kesempatan untuk menyelesaikan studi

\section{DAFTAR PUSTAKA:}

Babady, N. Esther., Nancy L, Wengenack. 2012. Clinical Laboratory Diagnostics for Mycobacterium tuberculosis. Dalam buku Understanding Tuberculosis - Global Experiences and Innovative Approaches to the Diagnosis. Rijeka, Croatia : Intech Publisher

Badan Penelitian dan Pengembangan Kesehatan Kementerian Kesehatan RI. 2013. Laporan Riset Kesehatan Dasar 2013. Jakarta : Kementerian Kesehatan Indonesia. 
Jurnal Biosains Pascasarjana Vol. 17 (2015) pp

(C) (2015) Program Pascasarjana Universitas Airlangga, Indonesia

Chandra, Jimmy., Wieke Triestianawati, Retno Kadarsih. 2011. Infeksi Mikobakterium Atipikal. Jurnal Media Dermato-Venereologica Indonesiana Vol. 38.No.2 Tahun 2011: 104-111

Dachlan, Yoes Prijatna. 2013. Imunologi Tuberkulosis : Sistem Imun, Pembentukan Granuloma, Dormansi, Reaktivasi Infeksi Laten,MDR-Tuberkulosis. The Problem of MDR TB from Basic To Clinic and Community. Surabaya : Rumah Sakit Penyakit Tropik Infeksi Universitas Airlangga Hal. 1-16

Dahlan, S. 2014. Langkah Membuat Proposal dan Cara Pengambilan Sampel dalam Penelitian Kedokteran. Jakarta : Sagung Seto

Dewi, Sakinah. 2012. Pengaruh Sanitasi Lingkungan Rumah, Penghasilan Keluarga dan Upaya Pengendalian terhadap Kejadian Penyakit TB Paru pada Ibu Rumah Tangga di Puskesmas Mulyorejo Kabupaten Deli Serdang Tahun 2012. Universitas Sumatera Utara Repository handle no. 123456789/33480

Dinas Kesehatan Prov. Kalimantan Selatan, 2013. Profil Kesehatan Provinsi Kalimantan Selatan Tahun 2012. Banjarmasin : Dinas Kesehatan Prov. Kalimantan Selatan

Dirjen Bina Upaya Kesehatan, 2012. Standar Prosedur Operasional Pemeriksaan Mikroskopis TB. Jakarta : Kementerian Kesehatan RI
Ganguly, Nilandri., Pawan Sharma. 2012. Mycobacterium tuberculosis RD-1 Secreted Antigens as Protective and Risk Factors for Tuberculosis. Dalam buku Understanding Tuberculosis - Global Experiences and Innovative Approaches to the Diagnosis. Rijeka, Croatia : Intech Publisher

Gustiani, Nenny., Ida Parwati, Anna Tjandrawati, Leni Lismayanti. 2014. Validitas Pemeriksaan Complex Specific Antigen Mycobacterium tuberculosis Region of Difference 1-3 Metode Rapid Immunochromatography pada Sputum Penderita Tuberkulosis Paru. MKB Volume 46 No. 4, Desember 2014 Hal 241-246

Hopprich, Ryan, Lisa Shephard, Bopha Teing, Sonia Krali, Annette Smith dan Richard Lumb, 2014. Evaluation of (SD) MPT64 Antigen Rapid Test, for Fast and Accurate Identification of Mycobacterium tuberculosis Complex. Microbiology and Infectious Diseases Directorate, SA Pathology, Adelaide, South Australia, Australia. Pathology (Impact Factor: 2.19). 10/2012; 44(7). DOI: 10.1097/PAT.0b013e3283 59d565

Kleinnijenhuis, Johanneke., Marije Oosting, Leo A. B. Joosten, Mihai G. Netea, dan Reinout Van Crevel. 2011. Innate Immune Recognition of Mycobacterium tuberculosis. Hindawi Publishing 
Jurnal Biosains Pascasarjana Vol. 17 (2015) pp

(C) (2015) Program Pascasarjana Universitas Airlangga, Indonesia

Corporation Clinical and Developmental Immunology. Volume 2011, Article ID 405310, 12 pages

Kusuma, Chandra. 2007. Diagnostik Tuberkulosis Baru. Sari Pediatri, Vol. 8, No. 4 (Suplemen), Mei 2007: 143 151

Malla, Bijaya. 2013. Molecular Epidemiology of Mycobacterium tuberculosis in Nepal. Tidak diterbitkan (Disertasi). Basel, Switzerland : Fakultas Ilmu Filsafat Universitas Basel Switzerland Martin,A.. D. Bombeeck, W. Mulders, K. Fissette, P. De Rijk, J. C. Palomino. 2011. Evaluation of the TB Ag MPT64 Rapid test for the identification of Mycobacterium tuberculosis complex. The International Journal of Tuberculosis and Lung Disease. Volume 2012 15(5):703-705 doi:10.5588/ijtld.10.0474

Mishra, Vashishth., Saranjit Singh, Rajesh Bareja, Rahul Kumar Goyal, Rabindra Nath Behara. 2014. Evaluation of Various Techniques Among Clinically Suspected Patients of Pulmonary Tuberculosis with and without The Presence of HIV Infection. IOSR Journal of Dental and Medical Sciences (IOSR-JDMS) e-ISSN: 22790853, p-ISSN: 22790861.Volume 13, Issue 8 Ver. IV (Aug. 2014), PP 68-71

Rastogi, Nalin dan Christopher Sola. 2007. Molecular Evolution of the Mycobacterium tuberculosis
Complex. Tuberculosis 2007 From Basic Science to Patient Care First Edition. www.TuberculosisTextbook. com. Hal. 53-92

Sari, Sri Kartika. 2011. Nilai Diagnostik Antigen TB dengan Rapid Test Device (Tb Ag) untuk Tuberkulosis Paru. Tidak Diterbitkan. Tesis. Surabaya : Fakultas Kedokteran Universitas Airlangga Surabaya Wahyuningsih, Esther. 2014. Pola Klinik Tuberkulosis Paru di RSUP Dr. Kariadi Semarang Periode Juli 2012-Agustus 2013. Jurnal Media Medika Muda Vol.3 No.1 (2014) Hal. 1-19

WHO, 2014. WHO Global Tuberculosis Report 2014. Geneva, Switzerland : World Health Organization. 